\title{
Tegumentary and Visceral Leishmaniases in Brazil - Emerging Anthropozoonosis and Possibilities for Their Control ${ }^{1,2}$
}

\author{
Leishmanioses Tegumentar e Visceral no Brasil - Antropozoonoses \\ Emergentes e Perspectivas de Controle
}

\author{
Mauro Célio de A. Marzochi \\ Keyla Belízia F. Marzochi ${ }^{3}$
}

\begin{abstract}
MARZOCHI, M. C. A. E MARZOCHI, K. B. F. Tegumentary and Visceral Leishmaniases in Brazil - Emerging Anthropozoonosis and Possibilities for Their Control. Cad. Saúde Públ., Rio de Faneiro, 10 (supplement 2): 359-375, 1994.

The existence of a number of different species of Leishmania, the persistent increase in the infection rate of diseases caused by this parasite (tegumentary and visceral forms), the different epidemiological situations found in regions of both recent and older colonization, and the trend towards urbanization have led to the adoption of different strategies to control leishmaniases in Brazil. The control measures involve studies related to the parasite, vectors, sources of infection (animal and human), clinical aspects, geographical distribution, historical and socioeconomic factors, integration of health services, and adequate technologies for diagnosis, treatment, and immunoprophylaxis. Finally, successful control requires work with human communities, involving education, provision of information, health promotion, and participation of these communities in the planning, development, and maintenance of control programs.
\end{abstract}

Key words: Leishmaniases; Clinical Classification; Vector Control; Lutzomyia sp.;

Community Participation

\section{INTRODUCTION}

The importance of leishmaniasis in the world is increasing every day. The World Health Organization (WHO) has estimated that 350 million people are exposed to the risk of becoming infected and that 12 million people are already infected (WHO, 1990). Leishmaniasis is widely distributed in the Americas, from the southern United States to northern Argentina.

${ }^{1}$ Part of this study was presented at the Brazilian National Workshop on Leishmaniases. Centro de Pesquisa Aggeu Magalhaes (CPqAM), Recife, Brazil (September 13-17, 1993).

${ }^{2}$ This work received financial supported from the World Health Organization (WHO/TSA), $n^{\circ} 910167$ and Conselho Nacional de Desenvolvimento Científico e Tecnológico (CNPq), Brazil.

${ }^{3}$ Departamento de Ciências Biológicas da Escola Nacional de Saúde Pública. Rua Leopoldo Bulhões, 1480, $6^{\circ}$ andar, Rio de Faneiro, RF, 21041-210, Brasil.
Leishmaniases occur in almost all states of Brazil. Between 1980 and 1991, the Ministry of Health recorded a yearly mean of 22,000 new cases of American tegumentary leishmaniasis (ATL) and 1,500 new cases of American visceral leishmaniasis (AVL) (MS/FNS/Cenepi, 1992).

In recent years there has been an increase in the incidence of both tegumentary and visceral leishmaniasis in all the geographical regions of Brazil (Vieira et al., 1990; MS/FNS/Cenepi, 1992; Gomes, 1992)(Figure 1).

In 1990-1991, the Northeast, which was settled long ago, had a higher absolute number of cases of ATL than Amazonia (the North), which was settled more recently ( 21,891 as compared to 13,323 cases). In the State of Maranhão, which includes part of the pre-Amazonian region, ATL has displayed a trend similar to that observed in Ceará northeastern Brazil (Figure 2). During the 
FIGURE 1. Geographical Distribution of American Tegumentary Leishmaniasis (1) and American Visceral Leishmaniasis (2) in Brazilian States of Known Leishmania Species; Percentage of ATL and AVL Cases by Regions (3) and the Primitive Distribution of Brazilian Forest Areas (4)
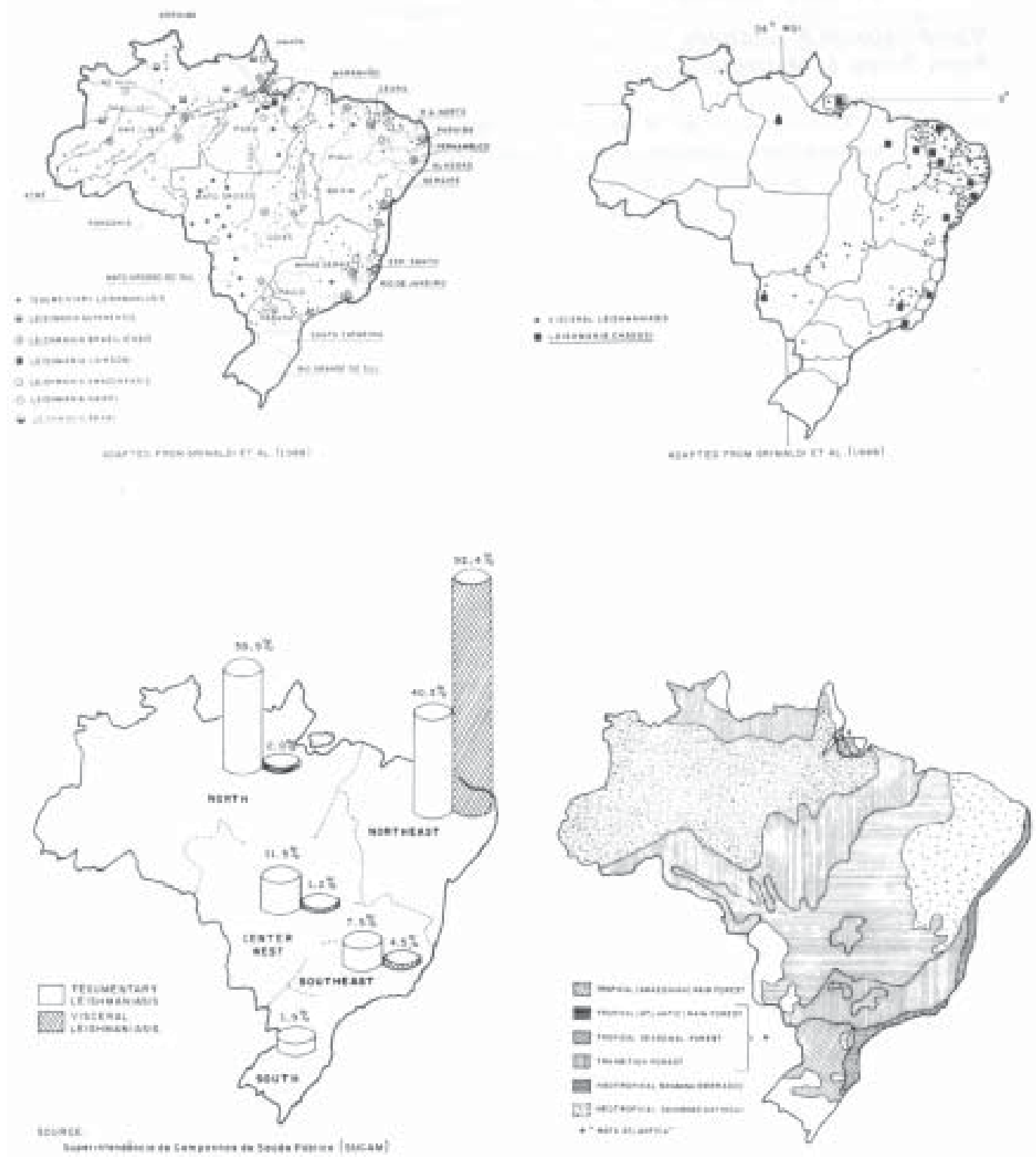
FIGURE 2. Reporting of American Tegumentary Leishmaniasis Cases in Brazil by Geographic Region (A), Comparative Distribution Between the North and Northeast Regions and the States of Maranhão (in the pre-Amazon) and Ceará (Northeast), from 1980 to 1991
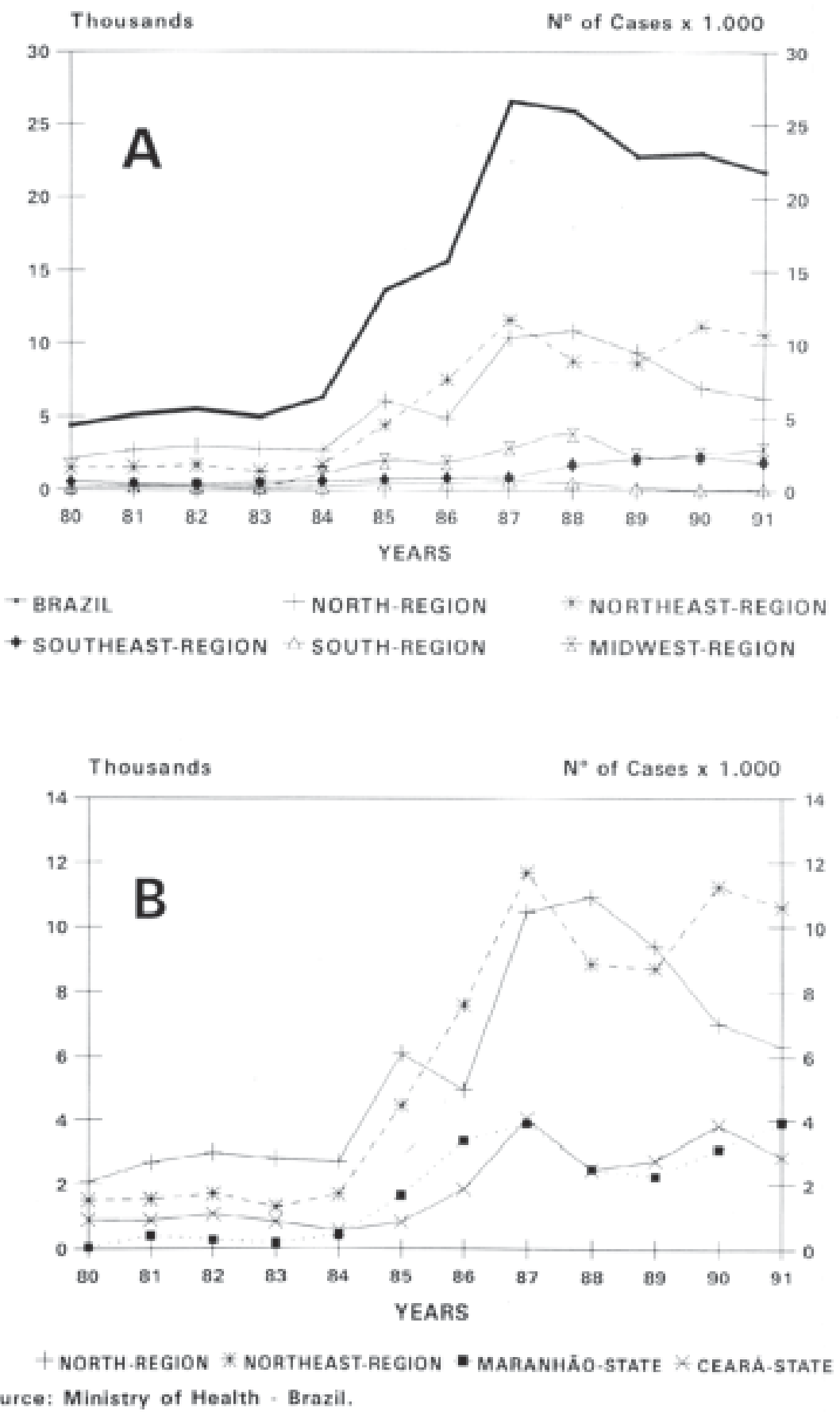
same period, there were 2,491 cases of AVL in the Northeast, or $92.4 \%$ of all cases of visceral leishmaniasis in Brazil, with a tendency towards the growth and geographical expansion of this endemic disease (MS/FNS/Cenepi, 1992). In northeastern Brazil, the States most affected by AVL are Bahia, Ceará, Piauí, and Maranhão (Figure 3).

Environmental changes caused by humans have modified the epidemiological profile of leishmaniasis in areas where transmission is related to wildlife, as well as in areas where transmission is in rural periurban or urban neighborhoods and areas surrounding households. In such areas, transmission depends on the adaptation of certain sandfly species (potential vectors) to these altered environments and involves domestic animals (L. chagasi, causing the visceral form of leishmaniasis, and L. braziliensis, causing the cutaneous and mucous forms) (Tolezano et al., 1980; Lainson, 1989; Marzochi, 1992).
ATL incidence is over 200 cases $/ 100$ thousand inhabitants in the States of Rondonia, Roraima, Amapá and Mato Grosso, and over 30/100 thousand inhabitants in the States of Maranhão and Ceará (Vieira et al., 1990).

However, probably due to its low mortality rate, ATL is one of the endemic diseases which receives least attention from public authorities (Marzochi \& Marsden, 1991).

On the other hand, AVL, with a high mortality rate, has received more attention, although both diseases have been included among the most important endemic diseases given priority by WHO (Ashford et al., 1992; Wijeyaratne et al., 1992).

At least seven species of Leishmania have been identified in Brazil as causing human disease (Grimaldi Jr. \& Tesh, 1993) belonging to subgenus Viannia and Leishmania (Lainson \& Shaw, 1987).

FIGURE 3. Distribution of American Visceral Leishmaniasis Cases in Brazil by Geographic Region and States with Highest Incidence Rates, from 1980 to 1991

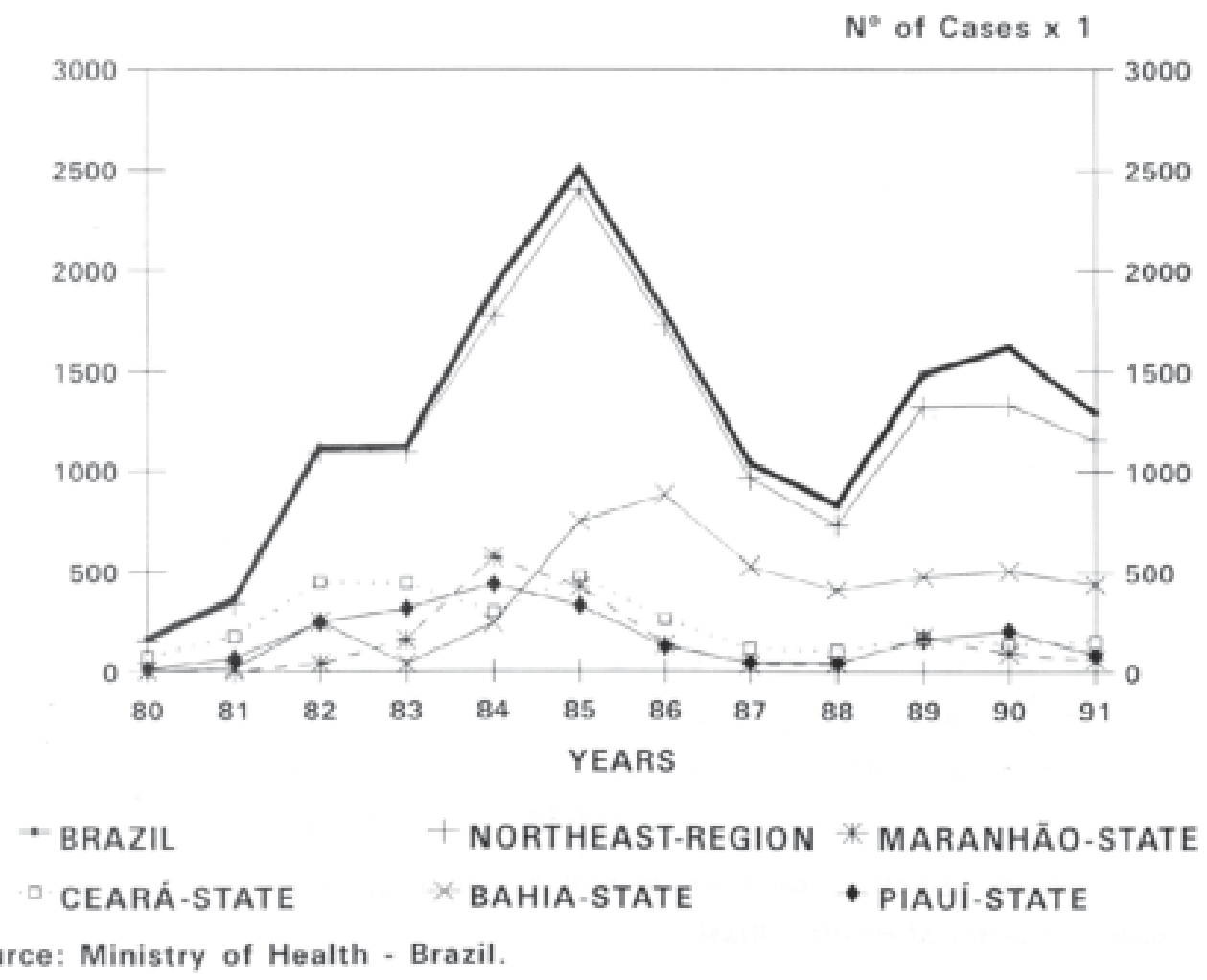


Leishmania (V.) braziliensis causes cutaneous and mucous lesions, is found from northern to southern Brazil in areas of recent as well as older colonization, and is associated in the latter with domestic animals such as dogs and horses. Transmission is associated with the following vectors: Psychodopigus wellcomei in primary terra firme (solid ground) forest in the State of Pará, the southern Amazon basin, and the Serra do Baturité mountain range in the State of Ceará, where sylvatic hosts are unknown; Lutzomyia whitmani in areas of caatinga (brush forest), cerrado (savannah), and ancient Mata Atlântica (Atlantic coastal forest) in the northeastern States of Maranhão, Ceará, Pernambuco and Bahia, the centralwestern States of Mato Grosso and Goiás, and the southeastern State of Minas Gerais; and Lu. intermedia (probably Lu. migonei and Lu. fisheri also) in areas of ancient Mata Atlântica in the southeastern States of Espírito Santo, Rio de Janeiro, and São Paulo and araucaria vegetation in the southern States of Paraná (Aguiar et al., 1989) and Santa Catarina (São Tiago \& Guida, 1990). Outside of Amazonia, dogs (Falqueto et al., 1986; Pirmez et al., 1988), horses, donkeys, mules (Aguilar et al., 1989; Yoshida et al., 1990, Barbosa-Santos et al., 1991), and possibly synanthropic rodents (Araújo-Filho et al., 1981; Vasconcelos et al., 1987), as well as humans, are considered sources of infection for sandfly vectors (Marzochi, 1992). Within the primary forest of the remaining Mata Atlântica, for example, populations of $L u$. withmani and Lu. intermedia are small (Aguiar et al., 1989), while in areas of recent or mainly past deforestation, populations of Lu. withmani are greatly increased in dry rural areas of the interior (Jones et al., 1987), as are populations of $\mathrm{Lu}$. intermedia in coastal and in damp river valleys in rural and peridomiciliary areas (Aragão, 1927; Lima, 1986; Gomes et al., 1986).

Periurban and rural population in endemic areas are permanently expose to infective phlebotomine bites. Results from Montenegro skin test and serological tests show a high positive rate, suggesting the existence of subclinical or hidden forms of the disease (Marzochi et al., 1980).

In the areas involving $L$. braziliensis, the rate of positive skin test increases with age (20 - 30\% on average) and reinfections are fairly rare (Sabroza, 1983; Mendonça et al., 1986). The same parasite can persist and be reisolated from scars of appropriately treated lesions as long as eight years after treatment (Schubach et al., 1987).

Thus, outside the Amazon region, it is very likely that $L$. braziliensis does not form part of the natural foci (involving forest/wild reservoirs and vectors), but rather has been introduced into the areas by man or domestic and synanthropic animals, in modified environments where the population of sandflies has increased due to recent or past human activities, which have probably led to a decline in the sandflies' natural enemies, along with a greater supply of blood as feed (Marzochi, unpublished observations).

Historically, two major periods of growth and expansion of ATL have been observed outside the Amazon region. The first occurred from the end of the last century until the early decades of this century, coinciding with the wave of migration from the Northeast of Brazil, mainly from the State of Ceará to Amazonia, as a result of the great drought which occurred in the Northeast (1877-1880). The migrants remained in Amazonia during the period of rubber extraction, until its decline (1912-1932). Thereafter, they returned to the Northeast or migrated to developing areas of the Southeast of Brazil, particularly Minas Gerais and northwestern São Paulo State, during the expansion of coffee cultivation, from 1930 onwards, when the great ATL epidemic began (Pessoa \& Barretto, 1948).

The rubber extraction area in the Amazon region was confined almost exclusively to tributaries on the right side of the Amazonas and Solimões rivers, in the south of the Amazon basin, where L. braziliensis predominates.

The other period of growth took place from the latter half of the 1960s onwards, coinciding with the interruption of malaria 
control activities in many geographic areas outside the Amazon region and intense migration from all areas of Brazil to the South of Amazonia, during the process of colonization, and more recently during the gold-mining period beginning in the late 1970s, coinciding with the prohibition of use of residual-action insecticides

(organochlorides) in agriculture. The return of these workers and gold miners coincided with the reappearance of the disease in a number of states, as well as its recent appearance in southern Brazil and neighbouring countries (Paraguay), which were host to large numbers of immigrants from Amazonia (Marzochi, unpublished observations). Currently the most troublesome aspect is the urbanization of the disease, occurring in Rio de Janeiro and Belo Horizonte in the State of Minas Gerais (Oliveira-Neto et al., 1987; Passos et al., 1993).

The considerable genetic heterogeneity observed between different strains of $L$. braziliensis isolated from southern Amazonia (Gomes et al., 1993), in contrast with the intraregional homogeneity of strains of the same species isolated from different geographical regions of Brazil (Lopes et al., 1984; Gomes et al., 1993), reinforces the hypothesis of the introduction and adaptation of these strains to new environments.

Leishmania $(V$.) guyanensis causes predominantly ulcerative cutaneous lesions. It occurs only in northern Amazonia in areas of recent colonization and is related to wild animals such as the Choloepus didactilus two-toed sloth, Tamandua tetradactila, Didelphis marsupialis and Proechimys guyanensis in primary and secondary forests. The sandflies involved in its transmission are Lu. umbratilis, Lu. anduzei and Lu. whitmani in primary solid ground forest in the northern Amazon basin and following deforestation (Barret \& Senra, 1989). In Manaus, in the State of Amazonas, the trend towards urbanization of L. guyanensis on the outskirts of the city has been a major cause of concern.

Leishmania (L.) amazonensis causes cutaneous and occasionally diffuse (anergic) lesions, associated with wild rodents (Proechimys and Oryzomys) and marsupials.
It rarely occurs in humans. The vectors incriminated are Lu. flaviscutelata and $L u$. olmeca nociva in igapós (interconnecting Amazon river channels), primary, and secondary solid ground forest and lowlands in the Amazon basin. L. amazonensis also occurs in the Northeast (Maranhão and Bahia), Southeast (Minas Gerais), and Central West (Goiás) (Lainson, 1989).

Leishmania (V.) lainsoni causes ulcerative cutaneous lesions, is infrequent in humans, and is associated with wild rodents (like the Agouti paca) in primary and secondary forests in the Amazon Region. Lu. ubiquitales, the vector incriminated, is not very anthropophylic (Silveira et al., 1987).

Leishmania (V.) naiffi rarely causes ulcerative cutaneous lesions in humans. It is associated with armadillos, Dasypus novencinctus (Edentata), in primary forests in the Amazon Region. It is related to the presence of $L u$. isquamiventris, $L u$. paraensis, and Lu. ayrozai (Lainson et al., 1990b).

Leishmania (V.) shawi causes single cutaneous lesions and is associated with wild animals like Primata (Cebus and Chiropotes), Edentata (Choloepus and Bradypus), and Carnivora (Nasua) in primary forests in the Amazon Region. It can be transmitted by $L u$. whitmani (Shaw et al., 1991).

Leishmania $(L$. $)$ chagasi causes the visceral form of the disease, with fever, anemia, hepatosplenomegaly, and progressive weight loss. It occurs chiefly in the Northeast but has been spreading, especially in areas of greater poverty in the country. It is a rural, periurban, and sometimes urban zooanthroponosis with domestic dogs acting as a major source of infection. Transmission is associated with $L u$. longipalpis, a sandfly with eclectic feeding habits. In recent years, AVL has been occurring in urban areas of several northeastern Brazilian capital cities like São Luís, Maranhão State, Terezina, Piauí State, and Natal, Rio Grande do Norte State, as well as large cities in the southeastern region like Montes Claros, Minas Gerais State, and the city of Rio de Janeiro (Marzochi et al., 1994b), and is expanding to other areas of the country. In rural and sylvatic areas, foxes such as Lycalopex vetulus and Cerdocyon 
thous and the marsupial Didelphis albiventris are incriminated as primary hosts (Lainson et al., 1990a; Sherlock et al., 1984), associated with Lu. longipalpis.

In AVL, however, the considerable biochemical (Thomas-Soccol et al., 1993) and genetic (Lopes et al., 1984; Lopes \& Wirth, 1986) homogeneity observed among isolates of Leishmania chagasi from diverse regions of Brazil, as well as the similarities in its clinical behaviour with visceral leishmaniasis in the Mediterranean, suggest that this species of Leishmania could have been introduced into Brazil during the process of European colonization (Killick-Kendrik et al., 1980).

\section{DIAGNOSIS, REPORTING, AND CLINICAL/EPIDEMIOLOGICAL ASSESSMENTS OF ATL AND AVL}

Accurate diagnosis of leishmaniasis requires microscopic detection of Leishmania in tegumentary (cutaneous and mucosal) and visceral lesions (lymph nodes, bone marrow, spleen, liver). Material is collected by puncture or biopsy and examined in smears, impressions, or tissue sections using special histochemical staining techniques. Isolation and culture of the etiological agent allows for taxonomic characterization of the species using isoenzyme electrophoresis (Zimodemes), species-specific monoclonal antibodies (Serodemes), analysis of minicircle DNA heterogeneity (Schizodemes), etc (Grimaldi Jr. \& Tesh, 1993).

From the immunological point of view, the delayed hypersensitivity skin test (DHST) performed via interdermal inoculation of inert Leishmania antigen allows for detection of prior exposure of the individual to the parasite (with or without active disease) and the serological tests can detect circulating antibodies both in the active phase of the disease (absent, low and moderate titers in ATL and moderate to high titers in AVL) as well as in situations of repeated exposure of individuals with natural or temporary resistance to the infective bite of insect vectors in areas of active transmission (Marzochi et al., unpublished observations).
The incubation period for leishmaniases is the time interval between the inoculation of Leishmania by the infective insect vector (in which there are no signs or symptoms and no laboratory or immunological tests that can allow for diagnosis of the infection), the duration of which is poorly defined (20-40 days in ATL and weeks, months, or years in AVL).

Based on the manifestations and possibilities of ATL clinical evolution, from the site of the phlebotomine's bite the following groups and respective forms (Convit et al., 1972; Marzochi et al., 1980; Marsden, 1986; Costa et al., 1986; Ryan et al., 1990; Marzochi, 1992; Barral et al., 1992; Moraes et al., 1993; Marzochi \& Marzochi, 1994), can be defined:

1. Subclinical group or inapparent cutaneous leishmaniasis (ICL)

A relatively large proportion of individuals exposed to the infective bite of the vector do not develop cutaneous or regional lymphatic disease, and it is difficult to predict the individual potential for progression, whether self-resolving or of parasite-host equilibrium, capable of occasionally progressing to disease in the presence of a decline in local immunity (cutaneous traumas) or systemic immunity (HIV infection, immunosuppressive drugs). This state is characterized by the absence of a cutaneous lesion (active or healed), positive DHST, and occasionally positve serological tests.

2. Cutaneous group or cutaneous leishmaniasis (CL)

\section{a. Localized cutaneous form:} single or multiple cutaneous tegumentary lesion(s), generally ulcerated, in the proximity of the inoculation site; DHST is positive and serology occasionally positive. Treatment is effective and spontaneous cure occurs frequently. 
b. Disseminated cutaneous form: multiple cutaneous tegument lesions, generally small and ulcerated, distant from the inoculation site; DHST and serology are positive and treatment is effective.

c. Diffuse cutaneous form: nonulcerated multiple and papular and/or nodular cutaneous tegument lesions, distant from the inoculation site. DHST is negative and serology positive. Treatment is difficult or ineffective.

3. Mucosal group or mucosal leishmaniasis (ML)

a. Delayed mucosal form: internal mucosal lesions, generally multiple, associated with CL process scar(s) originated after its spontaneous or therapeutical healing; strong DHST, and serology is positive. Treatment is effective and should be prolonged.

b. Lone or isolated mucosal form of indeterminate origin: internal mucosal lesion(s), in the absence of active CL scars; DHST and serology are positive. Prolonged treatment is effective.

c. Primary mucosal form: external mucosal lesion occasionally exposed to the vector bite or to direct contagion (lips, glans), generally single, in the absence of active CL or scar(s). DHST is positive and serology occasionally positive.

4. Mixed group or associated mucocutaneous leishmaniasis (MCL)

a. Concurrent mucocutaneous form: active cutaneous and mucosal lesions, both simultaneous and distant; DHST and serology are strongly positive. Prolonged treatment is effective.

b. Contiguous mucocutaneous

form: mucosal lesion of continuity to the active or healed cutaneous lesion. DHST is positive and serology occasionally positive. Prolonged treatment is effective.

5. Lymph gland group or glandular leishmaniasis (GL)

Lymphatic development of indurated satellite lymphangitis and or lymphadenopathy may occur in all groups and forms, or even in the absence of a tegumentary lesion, thus characterizing the lymph gland group or glandular leishmaniasis with an initial glandular form. DHST may be negative and serology positive.

In relation to $\mathrm{VL}$, although the clinical course of the infection after parasite inoculation depends on factors which are as yet poorly-understood, once the disease becomes clinically apparent, its subsequent severity depends primarily on the length of time of clinical evolution. Occasionally the onset of symptoms may be sudden.

Considering various known classifications and observations in endemic areas (Rodrigues da Silva, 1957; Prata, 1957; Neves, 1978; Marzochi et al., 1985a; Badaró et al., 1986) and based on personal experience with active case search and spontaneous clinical demand (Marzochi et al., 1994a), we consider an evolutionary clinical/laboratory definition for infection/disease in AVL:

1. Subclinical form or inapparent visceral leishmaniasis (IVL). Characterized by the absence of clinical manifestations (signs and symptoms), presence of antibodies for Leishmania and/or positive DHST. Absence of clinical manifestations is based on a negative anamnesis and normal physical examination. It can reflect the initial infectious process that will eventually 
evolve to disease; involution, or the self-resolving phase of the initial process (the ideal parasite-host equilibrium relationship); or an immune post-disease residue in treated cases. The inapparent form of the disease can only be found through active search for cases. Treatment is normally not indicated in these cases, which should be subject to clinical follow-up.

2. Mild form, or Mild VL. Characterized by the absence of symptoms (individuals without clinical complaints), or where these occasionally occur (oligosymptomatic), they are sporadical and difficult to associate with VL; presence of signs at physical examination, including discrete hepatomegaly and/or splenomegaly; presence of antibodies for Leishmania, DHST generally positive, with or without evidence of Leishmania at organ puncture. This form can progress to the inapparent form or to symptomatic and serious forms, where a negative DHST may be a sign of alert for this possibilitiy. The mild form is also only found through active search (Marzochi, unpublished observations).

Such cases should be untreated unless long-term clinical follow-up can be ensured.

3. Moderate form, or Moderate VL. Characterized by a clinical history lasting for weeks up to a few months, with variable fever, episodes of diarrhea and occasionally other manifestations, yet with sustained overall clinical state, normal activity during the periods without fever, presence of discrete to moderate hepatomegaly, positive serological tests, occasionally postive DHST, evidence of Leishmania at bone marrow puncture or that of other organs or even at blood culture.

Complementary hematological and biochemical laboratory tests are moderately altered. Patients treated with antimonial generally progress well, with no complications. Untreated patients in this class are expected to progressively worsen their clinical condition.

4. Serious form, or Serious VL.

Characterized by insidious progression resulting from a late diagnosis in which patients refer to a history of months or years of the disease, leading progressively to a consumptive condition, with variable fever, increasing weakness, pallor, weight loss, increased abdominal volume, episodes of bleeding and diarrhea, and other manifestations. Inspecific clinical and laboratory tests point to a serious overall prognosis, huge

hepatosplenomegaly, anemia progressing to pancytopenia and hypoalbuminemia (with inversion of the albumin/globulin ratio), moderate alteration in hepatic and renal function tests. Progression of these alterations reflects worsening of the clinical condition with cardiac failure and edema up to anasarche, weight loss, and cachexia, petechial hemorrhages of the mucosae or skin, predominantly in areas of attrition and lower limbs, mild to moderate jaundice, arterial hypertension (generally with peaks), and secondary bacterial infections. Antibody titers are extremely high, DHST is negative, and Leishmania can be shown in bone marrow and other organ biopsies. Death occurs in this phase due to late treatment or absence of response to antimonial and other drugs, generally with complications. Death frequently occurs from bacterial sepsis and/or serious hemorrhage, sometimes even before treatment for leishmaniasis has been started or during the first few days of treatment. In the latter cases, aggravation of the clinical state may result from a Herxheimer type reaction, observed fairly frequently in the first few days of antimonial treatment, particularly in the advanced form of the disease (Marzochi, unpublished observations). 


\section{GENERAL CONTROL MEASURES}

General control measures for leishmaniases, because of their enormous complexity, must be divided into various areas of activity: humans, both susceptible or diseased, insect vectors, and domestic animal reservoirs. In practice, their application is restricted to specifically defined situations and places (Marzochi, 1992).

Identification and characterization of the transmission types -

domiciliary/peridomiciliary (domestic/rural), extradomiciliary (sylvatic), and accidental (laboratory, blood transfusion, organ transplant) - are fundamental for control measures.

In extradomiciliary transmission areas where vector and wildlife reservoir control is unfeasible, the construction and maintenance of houses at least 300 meters from forests, as well as individual measures (early diagnosis and treatment, protective clothing, utilization of insect repellent, vaccination etc.) are recommended. The vaccine proposed by Mayrink et al. (1979), based on the utilization of whole Leishmania antigen, is still in the evaluation process, aimed at ensuring greater immunogenicity, efficacy, and safety. The rate of protection identified to date, or some $50 \%$ of vaccinated individuals (Antunes et al., 1986) is still not sufficient as a single, isolated prevention measure, though it represents a major advance.

In areas of transmission in or around households, insecticide application can be used to combat the insect vector. In these areas, there is evidence that dogs, horses, donkeys, mules, and rodents may be epidemiologically significant for ATL, as are domestic dogs for AVL (Aguilar et al., 1989; Deane \& Deane, 1962).

\section{MEASURES FOR CONTROL IN THE TRANSMISSION CHAIN}

In drawing up a control program, integration of the different health services in the area is necessary to avoid duplication and needless waste. As a suggestion, the experimental adoption of a leishmaniasis mobile unit in a defined endemic area is recommended. It should consist of a vehicle, technical personnel, and a mobile field laboratory to collect and analyze biological material (Marzochi \& Marsden, 1991).

The peculiar characteristics of the reservoir animals and vectors and the variety of epidemiological situations have shown that control strategies must be flexible and designed to be applied specifically to each region or focus of infection. The complexity of control is more evident when one considers the innumerable gaps which still exist in knowledge about such aspects, including the geographical distribution of different species of Leishmania: L. chagasi, L. braziliensis, L. guyanensis, and L. amazonensis.

For the selection of appropriate strategies for each geographical region, we must consider the epidemiological analysis of data referring to the following:

1. Reporting of human cases, including the incidence and clinical form of the disease and the sex, age, and geographical origin and travels of patients;

2. Epidemiological studies to establish transmission dynamics (domiciliary/peridomiciliary and extradomiciliary transmission), entomological studies to define vector species (dispersion, anthropophilic, exophilic, and natural infection degree) and studies of reservoir animals (domestic and non-domestic);

3. Parasitological studies to define the species of etiological agent circulating in the focus of transmission, through isolation in culture using the vacupuncture technique (Marzochi et al., 1993) or inoculation in hamsters, and subsequent taxonomic characterization in established reference centers;

4. Further studies on ecological aspects as to vectors and reservoir animals involved.

As a result of this analysis, it will be possible to develop the following actions: 
a. Early diagnosis and treatment of human cases through the basic health network, providing ondemand health care, by notification and active search in areas of greatest morbidity or where the population's access to the health network is difficult.

In human visceral leishmaniasis, diagnosis is aided by serological examination and parasite demonstration by bone marrow or splenic puncture.

Diagnosis of human cutaneous leishmaniasis is aided by cutaneous hypersensitivity reaction, scraping and aspirating from the lesion to smear, and culture and animal inoculation for parasite isolation (Marzochi, 1982);

b. Early and periodical (every six months) animal diagnosis by serological examination, cutaneous hypersensitivity (Marzochi et al., 1987; Marzochi \& Barbosa-Santos, 1988), and parasitology for control, treatment (when feasible), and/or maintenance of dogs and equines in clean places and at a reasonable distance from human populations in ATL, and the elimination of dogs detected by serological testing in AVL;

c. Reduction of vector-human contact through:

- Educational measures, including community education by multiprofessional and multiinstitutional teams aimed at improving technical capacity, knowledge of the disease, and understanding of the life style of the populations at risk is fundamental. However, such efforts suffer the external effect of social, economic, political, and cultural factors.

- Entomological surveys, aimed at defining the transmission area and monitoring the effectiveness of applying insectides and discovering spatial distribution, density, and fluctuations of the vector in domiciliary and peridomiciliary environments and livestock or poultry shelters during the nocturnal period.

- Periodic insecticide application (every six months), when transmission in and around households occurs. Practicable in ATL where there is a prevalence of Lutzomyia intermedia

(Guimarães \& Bustamante, 1954; Lima et al., 1988), whose breeding places are near households, or in AVL where there is a prevalence of Lu. longipalpis (Deane et al., 1955), whose breeding places are farther from households, and less efficient where $L u$. whitmani (França et al., 1991) and other sylvatic sandflies (ALT) prevail.

- Individual protection measures, including human population settlement in safe areas. Use of nets with or without insecticide, use of repellents etc.

\section{CONTROL STRATEGIES}

Control strategies thus depend on the type of transmission observed in each particular region.

Where the disease is transmitted in forests, use of human tegumentary leishmaniasis vaccines is indicated, since combating sylvatic insect vectors would be unfeasible.

Where the disease is transmitted outside forests, control of insect vectors using insecticides can be done where transmission is domiciliary, as occurs where Lutzomyia intermedia or Lu. whitmani predominates for 
tegumentary leishmaniasis (in the Atlantic Forest in the Southeast and South of Brazil) and where Lu. longipalpis prevails for visceral leishmaniasis (as in the cerrado or savanna, semiarid areas, the Amazon and the Atlantic altered areas). However, ATL and AVL have spread in peripheral and central urban areas due to the appearance of new foci and expansion of old ones due respectively to a complete absence or lack of systematic control over insect vectors. In these same areas, domestic dogs can act as a major source of infection for the sandfly vectors, and utilization of canine leishmaniasis vaccines may be helpful (Marzochi et al., 1985b; Barbosa-Santos et al., 1987).

In areas where there is extradomiciliary transmission associated with Lutzomyia withmani (in the Atlantic Forest in the Northeast and the cerrado in the Southeast and Central West), spraying with insecticides is not effective, and the use of human tegumentary leishmaniasis vaccines is again indicated, as is immunization of domestic animals such as dogs and equids (Marzochi, 1992).

Wherever the disease is transmitted, an efficient reporting system for diagnosed cases is essential, in order to back up control activities and monitor their effectiveness.

Health education should be used to encourage the community to take part in early detection of cases and to trigger the reporting system.

\section{Institutional Responsibilities}

In relation to the definition of the responsibilities of health services at different levels and the decentralization already in progress, revision of the roles of different institutional sectors is necessary, not only in relation to patient care, but also to control (vectors, reservoirs, active search for cases).

We expect that the State and Municipal health departments will gradually take over epidemiological surveillance as well as patient care in their respective regions, under nationwide planning by the National Health Foundation (MS/FNS, 1991).

\section{Research Priority}

Priority should be given to research pertaining to the following aspects of control activities:

a. Diagnosis: practical and sensitive methods that can be used by local health personnel in areas where the disease occurs like citological staining techniques, DNA probes, detection of anti-Leishmania antibody in situ, etc.

b. Treatment: safe, effective drugs and treatment protocols that can be used orally (for Leishmania (V.) braziliensis and Leishmania (L.) chagasi infection) or topically (when infection has been proven to be by Leishmania $(V$. guyanensis or another dermotropic species).

c. Knowledge of the geographical distribution of Leishmania species and subspecies and their respective vectors.

d. Assessment of the characterization of the transmission types and the role of various sources of infection for insect vectors, such as wild animals, domestic animals and humans, mainly by $L$. braziliensis and L. chagasi, as well as in accidental transmission (blood transfusion and organ transplant in urban endemic areas).

e. Assessment of social, economic, and environmental factors favoring the presence, adaptation, or increase in the population species of sandflies, potential vectors for various forms of leishmaniases in new altered environments and surroundings, including urban, peri-urban, rural, and forest areas, in order to investigate the possibilities for monitoring risk situations.

f. Joint assessment (together with health services) of appropriate diagnostic, clinical, and epidemiological technologies produced by research institutions, with a view towards incorporating such technologies into control programs.

g. Studies for the development of an efficient and safe vaccine for 
vaccination of human groups exposed to a high risk of infection in ATL areas, as well as a vaccine for canine protection in AVL and ATL areas (associated with rabies vaccination to diminish operational costs).

h. In urban epidemic AVL, an assessment should be made as to the possibility of interrupting canine-vector contact through periodic treatment of all dogs — whether infected or not - with medicine used as systemic insecticides against ectoparasites (Cydectin or Ivermectin, for example) as a way of ruling out indiscriminate elimination of dogs.

i. In epidemic AVL and ATL, consideration should be given to the effect of periodic spraying of households and annexes, the walls and floors of shelters for domestic animals, the surface of peridomiciliary soil and vegetation with natural insecticides like the dry leaves of Nicotiana tabacum (uncut rolled tobacco leaves), the role of which as a repellent may be just as important as that of insecticides against sandflies. The main advantage is the extremely low cost and the possibility for participation by the local community in its application.

j. Action with human communities aimed at disseminating pertinent information and promoting health, meanwhile ensuring their participation in planning, implementing, and maintaining control programs.

\section{ACKNOWLEDGEMENTS}

We thank Drs. Christopher Peterson and Catherine Lowndes for proofreading the original manuscript and Mrs. Rogeria Pelegrino Pinho for secretarial assistance.

\section{RESUMO}

MARZOCHI, M. C. A. \& MARZOCHI, K. B. F. Leishmanioses Tegumentar e Visceral no Brasil - Antropozoonoses Emergentes e Perspectivas de Controle. Cad. Saúde Públ., Rio de Janeiro, 10 (suplemento 2): 359-375, 1994.

A ocorrência de várias espécies de Leishmania, o contínuo aumento das afecções causadas por esses parasitas (formas tegumentares e visceral) e as diferentes situações epidemiológicas encontradas, tanto em regiões de colonização recente quanto de colonização antiga, com tendência a urbanização, vem requerendo a adoção de diferentes estratégias para o controle dessas endemias no Brasil. Essas medidas demandam estudos relacionados aos parasitas, insetos vetores, fontes de infecção, aspectos clínicos, distribuição geográfica, fatores históricos e sócio-econômicos, integração dos serviços de saúde, tecnologias apropriadas de diagnóstico, tratamento e imunoprofilaxia. Finalmente, para o sucesso do controle, são requeridos esforços junto as comunidades humanas, envolvendo educação, provisão de informação, promoção da saúde e participação dessas comunidades no planejamento, desenvolvimento e manutenção dos programas adotados.

Palavras-Chave: Leishmanioses; Classificação Clínica; Controle de Vetores; Lutzmoyia sp.; Participação Comunitária

\section{REFERENCES}

AGUIAR, G. M.; VILELA, M. L.; FERREIRA, V. A. \& SANTOS, T. G., 1989. Ecologia dos flebótomos em um recente foco ativo de leishmaniose tegumentar no norte do Estado do Paraná (Diptera, Psychodidae, Phlebotominae). Memórias do Instituto Oswaldo Cruz, 84 (supl. IV): 07-08.

AGUILAR, C. M.; RANGEL, E. F.; FERNANDES, M.; MOMEM, H.; GRIMALDI Jr., G. \& VARGAS, Z., 1989. Leishmania (Viannia) braziliensis associated with domestic animals in Venezuela and Brazil. Memórias do Instituto Oswaldo Cruz, 84: 19-28. 
ANTUNES, C. M.; MAYRINK, W.; MAGALHÃES P.; COSTA, C. C.; MELO, M. N. N.; DIAS, M.; MICHALICK, M. S. N.; WILLIANS, P.; LIMA, A. O.; VIEIRA, J. B. \& SCHETTINI, A. P. M., 1986. Controlled field trials of a vaccine against New World cutaneous leishmaniasis. Internal Fournal of Epidemiology, 15: 572-580.

ARAGÃO, H. B., 1927. Leishmaniose tegumentar e sua transmissão pelos phlebótomos. Memórias do Instituto Oswaldo Cruz, 20: 177-185.

ARAÚJO-FILHO, N. A.; COURA, J. R. \& REIS, V. L. L., 1981. Leishmaniose tegumentar americana na Ilha Grande, Rio de Janeiro. III. Reservatórios silvestres e comensais. Revista do Instituto de Medicina Tropical de São Paulo, 14: 153-161.

ASHFORD, R. W.; DESJEUX, P.; DERAADT, P., 1992. Estimation of population at risk of infection and number of cases of leishmaniasis. Parasitology Today, 8: 104-103.

BADARÓ, R.; JONES, T. C.; CARVALHO, E. M.; SAMPAIO, D.; REED, S. G.; BARRAL, A.; TEIXEIRA, R. \& JOHNSON Jr., W. D., 1986. New perspectives on a subclinical form of visceral leishmaniasis. Fournal Infectious Disease, 148: 1003-1011.

BARBOSA-SANTOS, E. G. O.; MARZOCHI, M. C. A.; CONCEIÇÃO, N. F. \& SILVA, V. L., 1987. Field trial of vaccine against canine cutaneous leishmaniases in an endemic area of Rio de Janeiro. Preliminary results. Memórias do Instituto Oswaldo Cruz, 82 (suppl.): 153.

BARBOSA-SANTOS, E. G.; MARZOCHI, M. C.; URTADO, W.; QUEIROZ, F. \& CHICARINO, J., 1991. Immunotherapy and chemotherapy of mucocutaneous and disseminated cutaneoous leishmaniasis in a horse in Brazil. American Fournal of Tropical Medicine and Hygiene, 45 (suppl): 119.

BARRAL, A.; BARRAL-NETO, M.; ALMEIDA, R.; JESUS, A. R.; GRIMALDI Jr., G.; NETTO, E. M.; SANTO, I.; BACELAR, O. \& CARVALHO, E. M., 1992. Lymphadenopathy associated with Leishmania braziliensis cutaneous infection. American Fournal of Tropical Medicine and Hygiene, 47: 587-592.

BARRET, T. V. \& SENRA, M. S., 1989. Leishmaniasis in Manaus, Brazil. Parasitology Today, 5: 255-257.

CONVIT, J.; PINARDI, M. E.; RONDON, A. J., 1972. Diffuse cutaneous leishmaniasis: a disease due to an immunological defect in the host. Transactions of the Royal Society of Tropical Medicine and Hygiene, 66: 603-610.
COSTA, J. M. L.; MARSDEN, P. D.; LLANOSCUENTAS, E. A.; NETTO, E. M.; CARVALHO, E. M.; BARRAL, A.; ROSA, A. C.; CUBA, C. C.; MAGALHÃES, A. V. \& BARRETO, A. C., 1986. Disseminated cutaneous leishmaniasis in a field clinic in Bahia, Brazil. A report of eight cases. American Fournal of Tropical Medicine and Hygiene, 89: 319-323.

DEANE, L. M.; DEANE, M. P. \& ALENCAR, J. E., 1955. Observações sobre o combate ao Phlebotomus longipalpis pela dedetização domiciliária, em focos endêmicos de calazar no Ceará. Revista Brasileira de Malariologia e Doenças Tropicais, 7: 131.

DEANE, L. M. \& DEANE, M. P., 1962. Visceral leishmaniasis in Brazil: geographical distribution and transmission. Revista do Instituto de Medicina Tropical de São Paulo, 4: 198-212.

FALQUETO, A.; COURA, J. R.; BARROS, G. C.; GRIMALDI-FILHO, G.; SESSA, P. A.; CARIAS, V. R.; JESUS, A. C. \& ALENCAR, J. J. A., 1986. Participação do cão no ciclo de transmissão de leishmaniose tegumentar no município de Viana, Estado do Espírito Santo, Brasil. Memórias do Instituto Oswaldo Cruz, 81: 155163.

FRANÇA, F.; LAGO, E. L.; TADA, S.; COSTA, J. M. L.; VALE, K.; OLIVEIRA, J.; COSTA, $M$. A.; OSKAI, M.; CHEEVER, L.; NETTO, E. M.; BARRETO, A. C.; JOHNSON, W. D. \& MARSDEN, P. D., 1991. An outbreak of human Leihsmania (Viannia) braziliensis infection. Memórias do Instituto Oswaldo Cruz, 86: 169-174.

GOMES, A. C., 1992. Perfil epidemiológico da leishmaniose tegumentar no Brasil. Anais Brasileiros de Dermatologia, 67: 55-60.

GOMES, A. C.; SANTOS, J. L. F. \& GALATI, E. A. B., 1986. Ecological aspects of American cutaneous leishmaniasis. 4. Observations on the endophilic behaviour of the Sandfly and the vectorial role of Psychodopigus intermedius in the Ribeira Valley region of the São Paulo State, Brazil. Revista de Saúde Pública, 20: 280-287.

GOMES, R. F.; MACEDO, A. M.; SILVA, S. O.; PENA, S. D. J. \& MELO, M. N., 1993. Genetic relationships between Leishmania (Viannia) braziliensis isolated from different areas of Brazil. Memórias do Instituto Oswaldo Cruz, 88 (suppl.): 168.

GRIMALDI Jr., G.; TESH, R. B., 1993. Leishmaniases of the New World: Current concepts and implications for future research. Clinical Microbiology Review, 6: 230-250. 
GUIMARÃES, F. N. \& BUSTAMANTE, F. M., 1954. A aplicação domiciliar de DDT com base na profilaxia das leishmanioses: estudo de um foco de leishmaniose muco-cutânea cinco anos depois da asperção periódica com aquele inseticida. Revista Brasileira de Malariologia e Doenças Tropicais, 6: 127-130.

JONES, T.C.; JOHNSON, W. D.; BARRETO, A. C.; LADO, E.; BADARÓ, R.; CERF, B.; REED, S. G.; NETTO, E. M.; TADA, M. S.; FRANÇA, F.; WIESE, K.; GOLIGHTLY, L.; FIKRIG, E.; COSTA, J. M. L.; CIBA, C. C. \& MARSDEN, P. D., 1987. Epidemiology of American cutaneous leishmaniasis due to Leishmania braziliensis. fournal Infectious Disease., 153: 73-83.

KILLICK-KENDRICK, R.; MOLINEAU, D. H.; RIOUX, J. A.; LANOTTE, G.; LEANEY, A. J., 1980. Possible origins of Leishmania chagasi. Annals of Tropical Medicine and Parasitology, 74: 563-565.

LAINSON, R., 1989. Demographic changes and their influence on the epidemiology of the American leishmaniases. In: Demography and VectorBorne Diseases (MW Servicee, ed.), pp. 85-106, Boca Raton: CRC Preess.

LAINSON, R.; DYE, C.; SHAW, J. J.; MACDONALD, D. W.; COURTENAY, O.; SOUZA, A. A. A. \& SILVEIRA, F., 1990a. A Amazonian visceral leishmaniasis - Distributions of the vector Lutzomyia longipalpis (Lutz \& Neiva) in relation to the Cerdocyon thous (Linn.) and the efficiency of this reservoir host as a source of infection. Memórias do Instituto Oswaldo Cruz, 85: 135-137.

LAINSON, R.; SHAW, J. J.; SILVEIRA, F. T.; BRAGA, R. R. \& ISHIKAWA, E. A. Y., 1990b. Cutaneous leishmaniasis of man due to Leishmania (Viannia) naiffi Lainson \& Shaw, 1989. Annales de Parasitologie Humaine et Comparée, 65: 282-284.

LAINSON, R. \& SHAW, J. J., 1987. Evolution, classification and geographical distribution. In: The Leishmaniases in Biology and Medicine (W. Peters \& K. Killick-Kendric, eds.), vol. 1, pp. 1120, London: Academic Press.

LIMA, L. C., 1986. Ruralização da Lutzomyia intermedia, um provável caso de pré-adaptação. Revista de Saúde Pública, 20: 102-104.

LIMA, L. C. R.; MARZOCHI, M. C. A.; SABROZA, P. C. \& SOUZA, M. A., 1988. Observações sobre leishmaniose tegumentar cinco anos após profilaxia. Revista de Saúde Pública, 22: 73-77.

LOPES, U. G.; MOMEM, H.; GRIMALDI Jr., G.; MARZOCHI, M. C. A.; PACHECO, R. S. \& MOREL, C. M., 1984. Schizodeme and zymode- me characterization of Leishmania in the investigation of foci of visceral and cutaneous leishmaniasis. Fournal of Parasitology, 70: 89-98.

LOPES, U. G.; WIRTH, D. F., 1986. Identification of visceral Leishmania species with cloned sequences of kinetoplast DNA. Molecular Biochemistry Parasitology, 20: 77-84.

MARSDEN, P. D., 1986. Mucosal leishmaniasis ("espundia" Escomel, 1911). Transactions of the Royal Society of Tropical Medicine and Hygiene, 80: 859-876.

MARZOCHI, K. B. F; MARZOCHI, M. C. A.; ANDRADE, M. V.; SILVA, V. L.; GOMES, $M$. Z. R.; SILVEIRA, M. I. F. \& ALMEIDA, D. C., 1994a. Avaliação prospectiva da leishmaniose visceral autóctone no município do Rio de Janeiro. Revista da Sociedade Brasileira de Medicina Tropical, 27 (supl. 1), 257.

MARZOCHI, M. C. A., 1992. Leishmanioses no Brasil. As leishmanioses tegumentares. Fornal Brasileiro de Medicina, 63: 82-104.

MARZOCHI, M. C. A.; BARBOSA-SANTOS, E. G. O.; CONCEIÇÃO, N. F. \& SILVA, V. L., 1987. Epidemiological survey of canine cutaneous leishmaniases by intradermal reaction in an endemic area of Rio de Janeiro. Memórias do Instituto Oswaldo Cruz, 82 (suppl.): 163.

MARZOCHI, M. C. A.; BARBOSA-SANTOS, E. G. O., 1988. Evaluation of a skin test on the diagnosis of canine cutaneous leishmaniasis. Memórias do Instituto Oswaldo Cruz, 83: 391-392.

MARZOCHI, M. C. A.; COUTINHO, S. G.; SABROZA, P. C. \& SOUZA, W. J., 1980. Reação de imunofluorescência indireta e intradermorreação para leishmaniose tegumentar americana em moradores na área de Jacarepaguá (Rio de Janeiro). Estudo comparativo dos resultados observados em 1974 e 1978. Revista do Instituto de Medicina de São Paulo, 22: 149-155.

MARZOCHI, M. C. A.; COUTINHO, S. G.; SOUZA, W. J.; TOLEDO, L. M.; GRIMALDI-FILHO, G.; MOMEM, H.; PACHECO, R. S.; SABROZA, P. C.; SOUZA, M. A.; RANGEL-FILHO, F. B. \& TRAMONTANO, N. C., 1985a. Canine visceral leishmaniasis in Rio de Janeiro, Brazil. Clinical, therapeutic and epidemiological findings (1977-1983). Memórias do Instituto Oswaldo Cruz, 80: 349-357.

MARZOCHI, M. C. A. \& MARSDEN, P. P., 1991. Ecologia e controle de vetores - Leishmanioses. In: Encontro Nacional sobre Saude e Meio Ambiente (Fiocruz), pp. 31-36, Rio de Janeiro: Fiocruz.

MARZOCHI, M. C. A. \& MARZOCHI, K. B. F., 1994b. Proposta de uma classificação clínica 
simplificada para as leishmanioses tegumentares do novo mundo. Revista da Sociedade Brasileira de Medicina Tropical, 27 (supl. 1): 91.

MARZOCHI, M. C. A.; MARZOCHI, K. B. F. \& CARVALHO, R. W., 1994. Visceral leishmaniasis in Rio de Janeiro. Parasitology Today, 10: 37-40.

MARZOCHI, M. C. A.; SABROZA, P. C.; TOLEDO, L. M.; MARZOCHI, K. B.; TRAMONTANO, N. C. \& RANGEL-FILHO, F. B., 1985b. A leishmaniose visceral na cidade do Rio de Janeiro, Brasil. Cadernos de Saúde Pública, 1: 5-17.

MARZOCHI, M. C. A.; SOUZA, W. J. S.; COUTINHO, S. G.; TOLEDO, L. M.; GRIMALDI-FILHO, G. \& MOMEM, H., 1982. Evaluation of Diagnostic Criteria in Human and Canine Mucocutaneous Leishmaniasis in Rio de Janeiro District Where Leishmania braziliensis braziliensis Occurs. Anais da $9^{\text {a }}$ Reunião Anual de Pesquisa Básica em Doença de Chagas, Caxambu, Minas Gerais. (Mimeo.)

MARZOCHI, M. C. A.; TEIXEIRA, P.C.; MARZOCHI, K. B. F.; CONCEIÇÃO, N. F.; COUTINHO, W. \& BRITO, D. B., 1993. Vacuum aspiratory puncture system for Leishmania culturing, isolation and transport. Preliminary report. Revista do Instituto de Medicina Tropical de São Paulo, 35: 301-303.

MAYRINK, W.; COSTA, C. A.; MELO, M. N.; DIAS, M.; LIMA, A. O.; MICHALICK, M. C. \& WILLIAMS, P., 1979. A field trial of a vaccine against American dermal leishmaniasis. Transactions of the Royal Society of Tropical Medicine and Hygiene, 73: 385-387.

MENDONÇA, S. C.; COUTINHO, S. G.; AMENDOEIRA, R. R.; MARZOCHI, M. C. A. \& PIRMEZ, Z. C., 1986. Human American cutaneous leishmaniasis (Leishmania b. braziliensis) in Brazil: lymphoproliferative responses and influence of therapy. Clinical Experimental Immunology, 64: 269-276

MORAES, M. A. P.; CORREIA-FILHO, D. \& SANTOS, J. B., 1993. Linfadenopatias na leishmaniose tegumentar americana: considerações sobre dois casos. Revista da Sociedade Brasileira de Medicina Tropical, 26: 181-185.

MS (Ministério da Saúde) \& FNS (Fundação Nacional da Saúde - Dermatologia Sanitária), 1991. Guia de Controle de Leishmaniose Tegumentar Americana. Brasília, DF: MS.

MS (Ministério da Saúde); FNS (Fundação Nacional da Saúde) \& CENEPI (Centro Nacional de Epidemiologia), 1992. Informe Epidemiológico do SUS, 1: 30-33.

NAIFF, R. D.; FREITAS, R. A.; NAIFF, M. F.; ARIAS, J. R.; BARRET, T. V.; MOMEM, H. \&
GRIMALDI Jr, G., 1991. Epidemiological and nosological aspects of $L$. naiffi Lainson \& Shaw 1989. Memórias do Instituto Oswaldo Cruz, 86: 317-321.

NEVES, J., 1978. Leishmaniose visceral (Calazar). In: Diagnóstico e Tratamento das Doenças Infectuosas e Parasitárias (J. Neves, org.), pp. 658670, Rio de Janeiro: Guanabara Koogan.

OLIVEIRA-NETO, M.; MARZOCHI, M. C. A.; GRIMALDI Jr., G.; COUTINHO, S. \& PIRMEZ, C., 1987. Study of an outbreak of american cutaneous leishmaniasis (ACL) by $L . b$. braziliensis in a periurban area of the city of Rio de Janeiro, Brazil. 17 ${ }^{\text {th }}$ World Congress of Dermatology, Short Communications, Part II, p. 20, Berlin, Germany.

PASSOS, V. M. A.; FALCÃO, A. L.; MARZOCHI, M. C. A.; CONTIJO, C. M. F.; DIAS, E. S. \& KATZ, N., 1993. Epidemiological aspects of american cutaneous leishmaniasis in a periurban area of Belo Horizonte, MG, Brazil. Memórias do Instituto Oswaldo Cruz, 88: 103-110.

PESSOA, S. B. \& BARRETTO, M. P., 1948. Leishmaniose Tegumentar Americana. Rio de Janeiro: Ministério da Educação e Saúde, Centro de Documentação.

PIRMEZ, C.; COUTINHO, S. G.; MARZOCHI, M. C. A.; NUNES, M. P. \& GRIMALDI JÚNIOR, G., 1988. Canine American cutaneous leishmaniasis: a clinical and immunological study in dogs naturally infected with Leishmania of Rio de Janeiro, Brazil. American Fournal of Tropical Medicine and Hygiene, 38: 52-58.

PRATA, A. R., 1957. Estudo Clínico e Laboratorial do Calazar. Tese de Livre Docência, Salvador: Universidade Federal da Bahia.

RODRIGUES DA SILVA, J., 1957. Leishmaniose Visceral (Calazar). Tese de Livre Docência, Rio de Janeiro: Universidade Federal do Rio de Janeiro.

RYAN, L.; VEXENAT, A.; MARSDEN, P. D.; LAINSON, R. \& SHAW, J. J., 1990. The importance of rapid diagnosis of new cases of cutaneous leishmaniasis in pinpointing the sandfly vector. Transactions of the Royal Society of Tropical Medicine and Hygiene, 84: 789.

SABROZA, P. C., 1983. O Domicílio como Fator de Risco na Leishmaniose Tegumentar Americana. Estudo Epidemiológico em Facarepaguá, Município do Rio de Faneiro. Tese de Mestrado, Rio de Janeiro: Escola Nacional de Saúde Pública, Fundação Oswaldo Cruz.

SÃO TIAGO, P. T. \& GUIDA, U., 1990. Leishmaniose tegumentar no oeste do estado de Santa Catarina, Brasil. Revista da Sociedade Brasileira de Medicina Tropical, 23: 201-203. 
SHAW, J. J.; ISHKAWA, E. A. Y.; LAINSON, R.; BRAGA, R. R. \& SILVEIRA, F. T., 1991. Cutaneous leishmaniasis of man due to Leishmania (Viannia) shawi Lainson, de Souza, Povoa, Ishikawa \& Silveira, in Para State, Brazil. Annales de Parasitologie Humaine Comparée, 66: 243-246.

SHERLOCK, I. A.; MIRANDA, J. C.; SADIGURSKY, M. \& GRIMALDI Jr., G., 1984. Natural infection of the opossum Didelphis albiventris (Marsupialia Didelphidae) with Leishmania donovani in Brazil. Memórias do Instituto Oswaldo Cruz, 79: 515.

SCHUBACH, A.; MARZOCHI, M. C. A.; ARAÚJO, M. L. \& CONCEIÇAO, N. F., 1987. Healed lesion of cutaneous leishmaniasis. A positive culture for Leishmania sp. in the scar tissue, years after cure. Memórias do Instituto Oswaldo Cruz, 82 (suppl.): 6.

SILVEIRA, F. T.; SHAW, J. J.; BRAGA, R. R. \& ISHIKAWA, E. A. Y., 1987. Dermal leishmaniasis in the Amazon region of Brazil: Leishmania (Viannia) lainsoni sp.n., a new parasite from the State of Pará. Memórias do Instituto Oswaldo Cruz, 82: 289-292.

THOMAS-SOCCOL, V.; LANOTTE, G.; RIOUX, J. A.; PRATLONG, F.; MARTINI-DUMAS, A. \& SERRES, E., 1993. Monophyletic origin of the genus Leishmania Ross, 1903. Annales de Parasitologie Humaine Comparée, 68: 107-108.

TOLEZANO, J. E.; MACORIS, S. A. \& DINIS, J. M. P., 1980. Modificação na epidemiologia da leishmaniose tegumentar no Vale da Ribeira, Estado de São Paulo, Brasil. Revista do Instituto Adolfo Lutz, 40: 49-54.
VASCONCELOS, I. A. B.; VASCONCELOS, A. W.; LOPES, V. G.; SANTOS, A. N. M.; ABREU, R. M. R.; LIMA, J. W. O. \& ALENCAR, J. E., 1987. Reservoir hosts of L. b. braziliensis in a peculiar and coastal-sited focus of cutaneous leishmaniasis in Ceará state. Memórias do Instituto Oswaldo Cruz, 82: 200.

VIEIRA, J. B.; LACERDA, M. M. \& MARSDEN, P. D., 1990. National reporting of leishmaniasis: The Brazilian experience. Parasitology Today, 6: 339-344.

WIJEYARATNE, P.; GOODMAN, T. \& ESPINAL, C., 1992. Leishmaniasis control strategies. Parasitology Today, 8: 249-251.

WHO (World Health Organization), 1990. Expert Committee on the Control of the Leishmaniases, Geneva, 1989. Report. Geneva: WHO. (Technical Report Series, 793)

YOSHIDA, E. L. A.; CORREA, F. M. A.; MARQUES, S. A.; STOLF, H. O.; DILON, N. L.; MOMEM, H. \& GRIMALDI, Jr., G., 1990. Human, canine and equine (Equus caballus) leishmaniasis due to Leishmania braziliensis ( $=L$. braziliensis braziliensis) in the south-west region of São Paulo State, Brazil. Memórias do Instituto Oswaldo Cruz, 85: 133-134. 